\title{
THE REVERSAL OF IMPAIRMENTS OF PPE: A TEST OF FAIR VALUE ACCOUNTING
}

\author{
Domenico Campa \\ International University of Monaco, INSEEC Research Group \\ and \\ TongYu Cao and Ray Donnelly \\ University College Cork
}

\begin{abstract}
$\mathrm{T}$ his study examines if the reversal of impairments allowed by IAS 36 as undertaken by UK-quoted companies can be justified as unbiased adjustments to reflect the fair value of the property, plant and equipment assets to which they pertain. We test if the reversals are reflected in the change in stock market prices in an indirect test. We also employ a direct test to establish if the reversals are positively related to changes in subsequent operating performance. Our results suggest that the reversals of impairments are positively related to changes in future performance. Only those reversals that are undertaken when the pre-reversal net income is not negative are reflected in stock market returns. This is somewhat justified by the finding of a differential relation between the ability of the reversals to predict future operating performance and whether the firm is profitable pre-reversal or not. We argue that the results based on the direct test are more convincing and that our results support the decision of the IASB to allow the reversal of impairments.
\end{abstract}

\section{INTRODUCTION}

Fair value accounting allows managers to report relevant and timely information: it also provides them with the scope to obfuscate financial performance and position. This paper investigates which of the above approaches managers of firms quoted 
on the UK stock market choose to adopt. In particular, it tests if the reversal of impairments undertaken under the auspices of IAS 36 (International Accounting Standards) is used to faithfully represent the value of non-current assets or if they are used merely to boost current earnings.

The approach adopted here is based on that of Bernard (1993) and Aboody, Barth and Kasznik (1999), where changes in an asset's true value are assessed either indirectly with reference to changes in current stock price (return) or directly with reference to changes in future operating performance. If the reversal of the impairment reflects a change in the economic value of an asset, it will be positively associated with changes in current stock market performance and future operating performance. If reporting incentives underlie the decision to reverse the impairment, we should not observe these relations. Thus we examine if the reversal of property, plant and equipment (PPE) impairments of UK-quoted companies are associated with changes in stock price and changes in operating performance in the manner expected following a real increase in asset value. This approach is entirely consistent with the definition of an asset in the conceptual framework as 'a resource ... from which future economic benefits are expected to flow'.

There is a sharp contrast between the approaches taken by the Financial Accounting Standards Board (FASB) and the International Accounting Standards Board (IASB) to impaired assets that subsequently recover some, or all, of their value. The former views the impaired assets as being on a new cost basis and does not allow upward revaluations. The latter allows upward revaluations that not only increase the carrying amount of the asset to its fair value in the balance sheet but that also increase current income by the amount of the reversal of the impairment charge. From 2005, all companies whose shares are listed in the EU are required to prepare their consolidated financial statements in accordance with IASs and International Financial Reporting Standards (IFRSs) (which permit the reversal of impairment losses). The current study can be viewed as an effort to provide evidence to contribute to the debate on whether the FASB or the IASB has the correct approach in contexts where an impaired, non-financial, non-current asset's value may have recovered.

We use a sample of United Kingdom (UK) companies that have reversed their impairment of PPE over the period 2006-2011 and test if the reversal of their impairments is justified by their current stock return and future operating performance. We find strong support for unbiased reversal of impairments on the basis of the direct tests based on future operating performance. Our indirect tests based on stock return are not as clearcut but provide evidence that for firms with prereversal profits stock returns are positively related to the reversal of an impairment charge. Additional analyses reconcile the differences between our direct and indirect test results.

In the next section we review the pertinent literature. The third section outlines the hypotheses development and research methods. This is followed by a brief description of our sample and data. The penultimate section outlines our empirical results and the final section summarises the paper and concludes. 


\section{LITERATURE REVIEW}

The issue of impairment reversal of non-current assets is part of the debate pertaining to the advantages and disadvantages of fair value accounting relative to historical cost accounting. Fair value accounting is considered a better measurement for financial reporting because it reports the more up-to-date value of assets. The reporting of 'fairer' values of non-current assets helps investors make informed economic decisions in a timelier manner (Herrmann, Saudagaran and Thomas, 2006). However, historical cost valuation is more 'objective' than fair value valuation because the latter may be subject to much judgement and affords management the opportunity to manage earnings. Research has shown that fair values of financial assets and revalued investments are significantly associated with share prices (Barth, 1994; Nelson, 1996; Landsman, 1986; Barth and Clinch, 1998). Fair values of PPE are more difficult to calculate and more susceptible to manipulation than those of financial assets, meaning the findings regarding financial assets may not be applicable to fixed assets such as PPE. Nonetheless, Barth and Clinch (1998) show that revalued PPE is related to stock prices. Aboody et al. (1999) report that upward revaluations of fixed assets by UK firms predict future firm performance. They find that large downward revaluations are significantly and positively related to stock returns, but they also find that managerial incentives affect the usefulness of revaluations as the relationship between revaluations and firm performance is weaker for high debt-toequity firms. Easton, Eddey and Harris (1993) report similar effects for revaluations in Australia. Although impairment reversals also concern an asset's 'revaluation', they have a direct and positive impact on net income. It is therefore important to separately examine reversals to establish if they reflect changes in the economic fundamentals of the firm or if incentives for earnings management motivate them.

There is a considerable amount of literature exploring the effect of impairments of non-current assets, but research on their subsequent reversals of impairments is in short supply. The most important issue for investors is whether or not discretionary impairment losses/asset write-downs, as well as impairment reversals, are closely related to economic factors and are useful for economic decision-making.

Some studies have found evidence that discretionary impairment losses/asset writedowns provide useful information for investors (for example, Henry, 2009; LapointeAntunes, Cormier and Magnan, 2009; Li, Shroff, Venkataraman and Zhang, 2011).

However, there is also criticism of the fair value-based, asset impairment-related accounting standards. Titard and Pariser (1996) argue that the international accounting standards based on fair value accounting give managers considerable discretion as to the timing and the value of write-downs of impaired assets. When managers are provided with choices in determining the value of assets, expenses and the profits of their firms, the risk of aggressive accounting being employed is increased (Healy and Wahlen, 1999). There is extensive evidence of managers using impairment decisions opportunistically. Riedl (2004) and Sevin and Schroeder (2005), as well as Jordan and Clark (2004), document the use of impairment charges in big bath accounting. More recently, Bens, Heltzer and Segal (2011) find that the move to fair value accounting (Statement of Financial Accounting Standards (SFAS) No. 142) has somewhat reduced the information content of goodwill writeoffs. 
Upward revaluations on the basis of fair value are likely to be viewed with even more scepticism than downward revaluations; that is, impairments are likely to be trusted more than their reversals, given the incentives faced by management. Moehrle (2002) examines the reversal of restructuring charges using a sample of 121 reversals recorded between 1990 and 1999. He finds that managers are more likely to record reversals when pre-reversal earnings are below analysts' forecasts, when the firm experiences a pre-reversal loss or when pre-reversal earnings are below prior-year levels so as to avoid earnings declines. These results are consistent with firms using the restructuring accrual reversal to manage earnings upward.

Research that specifically pertains to the reversal of impairments of non-current assets is mostly undertaken in Asia although impairment reversals are practised in many jurisdictions. This is contradicted by Chen, Wang and Zhao (2009), who find that reporting incentives as a proxy for earnings management dominate managerial decision-making among publicly listed companies in China. A more recent study by Zhang, Lu and Ye (2010) also provides evidence of the opportunistic impairment reversal reporting by firms listed on Chinese stock exchanges.

Duh, Lee and Lin (2009) specifically examine the reversal of impairments under an IAS 36-based accounting standard in Taiwan. They report that firms with large impairment balances reverse their impairments when their pre-reversal earnings are lower than prior-year earnings. They also provide evidence that there is no stock market reaction to the reversal of impairments and infer that the market in Taiwan sees through the earnings management behaviour. They conclude that their results provide a rationale for the FASB's prohibition of the reversal of impairment losses.

It should be pointed out that if a reversal is not done on a timely basis it will be anticipated by the price performance of the company. Accordingly, there will be no contemporaneous price reaction to the delayed reversal of an impairment charge. Also, as pointed out by Aboody et al. (1999), stock return can be influenced by a firm's financing and other decisions, and thus only provides indirect evidence of future operating performance and hence a real change in asset value. Also in an Asian context, Shaari, Cao and Donnelly (2012) provide only partial support for findings by Duh et al. (2009). This paper reports that Malaysian companies on average reverse impairments when the true value of their assets recover. However, Shaari et al. (2012) also find evidence that a significant minority of firms in their sample that reverse impairments do so in order to manage earnings.

As well as being open to alternative interpretation, the results from Asian economies may not be applicable in Western economies where stronger corporate governance is likely to restrict opportunities for earnings management. Indeed, Ball (2006) makes specific mention of IAS 36 when he points out the likely variation in the institutional settings across IFRS-adopting countries. Trottier (2013) finds that Canadian managers are more likely to undertake a justifiable impairment if it can be reversed. This suggests that impairment charges may be more accurate if reversal is allowed. Trottier also reports that participants in that study reckon that a manager will be less likely to make an impairment charge if he has a bonus plan and cannot reverse the impairment. Therefore, it is worth reexamining the hypothesis/ claim, e.g. Duh et al. (2009), that there is a sound rationale for the prohibition of impairment reversals. We extend the analysis of Duh et al. (2009) by using a more 
direct approach to determining if the reversal of an impairment charge reflects a real change in asset values. In particular, we employ the method suggested by Bernard (1993) and employed by Aboody et al. (1999) to establish if the reversals are positively related to changes in future operating performance. We also examine the relationship between reversals and stock return.

\section{HYPOTHESIS DEVELOPMENT AND RESEARCH METHODS}

If an impairment reversal truly represents a contemporaneous increase in the value of an asset, it will be confirmed by other indications of real changes in valuation. One indication of an increase in the value of a company's assets is an increase in its share price. Accordingly, our first hypothesis in alternative form is:

H1: Reversals are positively associated with stock returns.

Following revaluation studies such as Easton et al. (1993), Barth and Clinch (1998) and Aboody et al. (1999), we use Equation 1 to test H1:

$R_{t}=\gamma_{0}+\gamma_{1} R E V_{t}^{\prime}+\gamma_{2}\left(N I_{t}-R E V_{t}^{\prime}\right)+u_{t}$

Firm subscripts are suppressed to facilitate presentation.

$\mathbf{R}_{\mathbf{t}}=$ stock market returns beginning eight months before the financial year-end and ending four months after the financial year-end.

$\mathbf{R E V}_{\mathbf{t}}{ }_{\mathrm{t}}=$ the reversal amount scaled by market value eight months before the fiscal year-end.

$\mathbf{N I}_{\mathbf{t}}-\mathbf{R E V}_{\mathbf{t}}=$ net income before reversal in year $t$ scaled by market value of equity eight months before fiscal year-end $t$.

H1 is tested with reference to the significance of $\gamma_{1}$. Specifically if $\gamma_{1}$ is significantly greater than 0 we can confirm that stock return corroborates the reversal of the impairment charge.

An increase in stock return arises because the market perceives that the future earnings and cash flows from the company's assets are likely to be greater than previously predicted. The return on a company's stock depends on factors other than future operating income such as the cost of capital, general market movements and technological changes. It also depends on whether the reversal is done on a timely basis and is not anticipated by the market. In effect, it is an indirect indication of value. Bernard (1993) points out that a more direct method for assessing if an asset's value has truly increased is to examine if the reversal of an impairment charge is associated with a positive change in future operating cash flows or income. This method was adopted by Aboody et al. (1999) to test for the reliability of revaluations of fixed assets in the UK. Accordingly, our second hypothesis, in alternative form, is:

$\mathrm{H} 2$ : Reversals of impairments are positively associated with changes in future operating cash flows and income.

Following Aboody et al. (1999), we estimate Equations 2 and 2a test H2. In addition to the revaluation, these equations include a historical cost estimate of an increase in asset value, and capital expenditure incurred during the year, as well 
as current operating performance as independent variables. If impairments are reversed for fundamental economic reasons, we expect that $\beta_{1}$ will be significantly positive. We also test if $\beta_{1}$ is equal to $\beta_{3}$ to establish if the fair value-based increase in asset value is related to future operating performance in the same manner as the historical cost increase in asset value. Equations $2 b$ and $2 c$ are versions of Equations 2 and 2 a respectively, augmented to include additional control variables.

$$
\begin{aligned}
& \Delta C F O_{t+\tau}=\alpha+\beta_{1} R E V_{t}+\beta_{2} \Delta C F O_{t}+\beta_{3} C A P E X_{t}+\varepsilon_{t} \\
& \Delta \text { PPIN }_{t+\tau}^{*}=\alpha+\beta_{1} R E V_{t}+\beta_{2} \Delta O P I N_{t}+\beta_{3} \text { CAPEX }_{t}+\varepsilon_{t} \\
& \Delta C F O_{t+\tau}=\alpha+\beta_{1} R E V_{t}+\beta_{2} \Delta C F O_{t}+\beta_{3} \Delta W C_{t}+\beta_{4} S I Z E_{t}+\beta_{5} M T B_{t}+\beta_{6} C A P E X_{t}+\varepsilon_{t} \\
& \Delta \text { OPIN }_{t+\tau}^{*}=\alpha+\beta_{1} R E V_{t}+\beta_{2} \Delta O P I N_{t}+\beta_{3} \operatorname{SIZE}_{t}+\beta_{4} M T B_{t}+\beta_{5} \text { CAPEX }_{t}+\varepsilon_{t}
\end{aligned}
$$

$\Delta \mathrm{CFO}_{\mathrm{t}+\tau}=$ the change in net cash flow from operations from year $t$ to $t+\tau$.

$\Delta \mathrm{CFO}_{\mathrm{t}}=$ the change in net cash flow from operations from year $t-1$ to year $t$.

$\Delta \mathrm{OPIN}^{*}{ }_{\mathrm{t}+\tau}=$ operating income before depreciation and amortisation expenses, reversal amount and abnormal working capital accruals (AWCA) over the period $t$ to $t+\tau$; $\tau=1$ or 2 .

$\mathrm{CAPEX}_{\mathrm{t}}=$ capital expenditure in year $t$.

$\mathrm{REV}_{\mathrm{t}}=$ the reversal amount for year $t$.

$\Delta \mathrm{WC}_{\mathrm{t}}^{\mathrm{t}}=$ change in working capital from year $t-1$ to year $t$.

$\mathrm{SIZE}_{\mathrm{t}}=$ the natural log of total assets at end of year $t$.

$\mathrm{MTB}_{\mathrm{t}}=$ the market to book value ratio at the beginning of year $t$.

All variables, except SIZE and MTB, are scaled by total assets at the end of fiscal year $t-1$.

\section{SAMPLE AND DATA}

The study examines the reversals of impairments made under IAS 36. Since IFRS became effective in the UK for financial statements beginning on 1 January 2005, we chose a sample period from 2006 to 2011 to facilitate the construction of our change variables. We require operating performance measures after the year of the reversal, and the most recent year for which financial data was available when we collected the data was 2012. Thus we used reversals made in financial years up until 2011. We downloaded details of reversals of impairments of PPE for all companies on the Datastream ${ }^{\circledR}$ lists UKQI and DeadUK. We found 228 reversals of impairments over the period 2006-2011. We deleted all companies with standard industrial classification (SIC) codes in the range 6400-6999. These are mainly financial services companies whose accounts are not prepared on the same basis as other companies. This reduced the sample size to 184 . Since we are examining the reversal of impairments made under the auspices of IAS 36, we removed all companies that do not prepare their accounts using IFRS from the sample. It should be noted that alternative investment market (AIM) companies did not have to adopt IFRS until 
1 January 2007. Consequently, the vast majority of deletions from our sample come from 2005 and 2006. Finally, 27 of the remaining companies did not have the requisite data to estimate our models, leaving us with 103 reversals.

Since impairments may be driven by industry effects, we compare the industrial classification of our sample with that of the Datastream List UKQI, which contains all active UK companies for which Datastream holds accounts data. This comparison is outlined in Table 1 and shows that Oil \& Gas and Basic Materials are over-represented in our reversal sample and consequently all other industries are under-represented. Further investigation reveals that most of our Basic Industries reversal companies are mining companies. Thus we conclude that the extractive industry is over-represented amongst reversal companies. We will return to this proclivity in our sample at a later stage when interpreting our results.

TABLE I: INDUSTRIAL CLASSIFICATION

\begin{tabular}{lrrrr}
\hline & \multicolumn{2}{c}{ Sample } & \multicolumn{2}{c}{ UK Industry } \\
& No. & $\%$ & No. & $\%$ \\
\hline Oil and Gas & 13 & 12.62 & 126 & 10.91 \\
Basic Materials & 31 & 26.50 & 166 & 14.37 \\
Industrials & 17 & 14.53 & 312 & 27.01 \\
Consumer Goods & 8 & 6.84 & 99 & 8.57 \\
Health Care & 0 & 0 & 77 & 6.67 \\
Consumer Services & 2 & 1.71 & 198 & 17.14 \\
Telecommunications & 18 & 17.48 & 19 & 1.65 \\
Utilities & 4 & 3.42 & 22 & 1.90 \\
Technology & 10 & 8.55 & 136 & 11.77 \\
Total & 103 & 100.00 & 1155 & 100.00 \\
\hline
\end{tabular}

\section{RESULTS}

Preliminary analysis of the data reveals some extreme outliers and indications that some variables have extremely skewed distributions. For example, cash flow from operations scaled by total assets in the year subsequent to the reversals has a maximum value of over 154, which makes no economic sense. Clearly, total assets of the firm in question are reduced to close to zero to give such a ratio. An outlier deletion program was accordingly devised. We removed up to four outliers greater than 2.5 standard deviations from the mean from the variable. The observations were deleted uniformly from both extremes of the distribution if the variable's distribution was symmetric. If the distribution was skewed positively or negatively, the outliers were deleted as appropriate. Descriptive statistics for the data are outlined in Table 2. These statistics were calculated after up to four extreme outliers were deleted from each variable. It is worth noting that the equity market value of companies in the sample extends from $£ 180,000$ to almost $£ 180$ billion. This may account for some of the outliers in variables that are scaled by the market value of equity. 
TABLE 2: DESCRIPTIVE STATISTICS

\begin{tabular}{|c|c|c|c|c|c|}
\hline Variable & Obs. & Mean & Stnd. Dev. & Min. & Max. \\
\hline $\mathrm{REV}_{\mathrm{t}}$ & 99 & 0.123 & 0.600 & 0.000 & 4.155 \\
\hline$R_{t}$ & 99 & 0.167 & 0.428 & -0.475 & 1.981 \\
\hline $\mathrm{NI}_{\mathrm{t}}-\mathrm{REV}_{\mathrm{t}}$ & 99 & 0.06 & 0.11 & -0.25 & 0.55 \\
\hline EXT & 103 & 0.33 & 0.47 & 0 & 1 \\
\hline $\mathrm{REV}_{\mathrm{t}}$ & 99 & 0.008 & 0.020 & 0.000 & 3.123 \\
\hline$\Delta \mathrm{CFO}_{\mathrm{t}}$ & 99 & 0.021 & 0.076 & -0.109 & 0.374 \\
\hline$\Delta \mathrm{CFO}_{\mathrm{t}+1}$ & 91 & 0.012 & 0.071 & -0.130 & 0.227 \\
\hline$\Delta \mathrm{CFO}_{\mathrm{t}+2}$ & 67 & $0.04 I$ & 0.103 & -0.100 & 0.324 \\
\hline$\Delta \mathrm{OPIN}_{\mathrm{t}}$ & 99 & 0.031 & 0.061 & -0.123 & 0.338 \\
\hline$\Delta \mathrm{OPIN}_{\mathrm{t}+1}$ & 91 & 0.028 & 0.070 & -0.088 & 0.348 \\
\hline$\Delta \mathrm{OPIN}_{\mathrm{t}+2}$ & 67 & 0.032 & 0.088 & -0.201 & 0.307 \\
\hline $\mathrm{MTB}_{\mathrm{t}}$ & 99 & 1.956 & 1.640 & 0.001 & 7.15 \\
\hline $\mathrm{SIZE}_{\mathrm{t}}$ & 96 & 13.850 & 2.513 & 4.357 & 17.811 \\
\hline CAPEX & 99 & 0.068 & 0.057 & 0 & 0.268 \\
\hline$\Delta W C$ & 99 & 0.019 & 0.112 & -0.261 & 0.386 \\
\hline
\end{tabular}

$R_{t}=$ stock market returns beginning eight months before the financial year-end and ending four months after the financial year-end.

$\mathrm{REV}_{\mathrm{t}}=$ the reversal amount scaled by market value 8 months before the fiscal year-end.

$\mathrm{NI}_{\mathrm{t}}-\mathrm{REV}_{\mathrm{t}}=$ net income before reversal in year $t$ scaled by the market value of equity 8 months before fiscal yearend $t$.

$\mathrm{REV}_{\mathrm{t}}=$ the reversal amount scaled by total assets at end of year $t$.

EXT is a dummy variable which takes the value of $I$ if the firm has an ICB sector code of 0530 (Oil \& Gas), 1750 (Industrial Metals and Mining) or 1770 (Mining) and zero otherwise.

$\mathrm{CFO}_{\mathrm{t}+\tau}=$ net cash flow from operations in year $t+\tau ; t$ scaled by market value at the end of year $t-I$.

$\Delta \mathrm{CFO}_{\mathrm{t}+\tau}^{\mathrm{t}+\tau}=$ the change in net cash flow from operations from year $t$ to year $t+\tau, \mathrm{CFO}_{\mathrm{t}+\tau}-\mathrm{CFO}_{\mathrm{t}}$

OPIN* ${ }_{t+\tau}^{t+\tau}=$ operating income before depreciation and amortisation expenses, reversal amount and AWCA in year $t+l$ divided by market value at end of year $t-I$.

CAPEX $X_{t}$ is capital expenditure in year $t$.

$\Delta \mathrm{OPIN}_{\mathrm{t}+\tau}^{*}=$ the change in operating income before depreciation and amortisation expenses, reversal amount from year $t$ to year $t+l$.

$\mathrm{CFO}_{\mathrm{t}}=$ net cash flow from operations in year $t$.

$\Delta \mathrm{CFO}_{\mathrm{t}}=$ the change in net cash flow from operations from year $t-l$ to year $t$.

$\mathrm{OPIN}_{\mathrm{t}}=$ operating income before reversals in year $t$ divided by total assets at end of year $t$.

$\Delta \mathrm{OPIN}_{\mathrm{t}}=$ the change in operating income before reversals from year $t-l$ to year $t$.

$\mathrm{SIZE}_{\mathrm{t}}=$ the natural log of sales at end of year $t-l$.

$M \mathrm{MB}_{\mathrm{t}}=$ the market value to book value ratio at the end of year $t-l$.

$\Delta \mathrm{WC}_{\mathrm{t}}=$ change in working capital from year $t-l$ to year $t$.

$\Delta \mathrm{CFO}_{\mathrm{t}+2}$ and $\triangle \mathrm{OPIN}_{\mathrm{t}+2}$ have a reduced number of observations since reversals with two years of subsequent performance are only available up until 2010: data for 2013 were not available when the data were collected.

A preliminary correlation analysis shows that $R E V$, the reversal scaled by opening total assets, is significantly positively correlated with the change in operating income over the subsequent 12 - and 24-month periods (see Table 3 ). It is also positively correlated with ICB, a dummy variable that takes the value of 1 for firms in the extractive industries and zero otherwise. Stock market return is significantly positively related 
The Reversal of Impairments of PPE: A Test of Fair Value Accounting

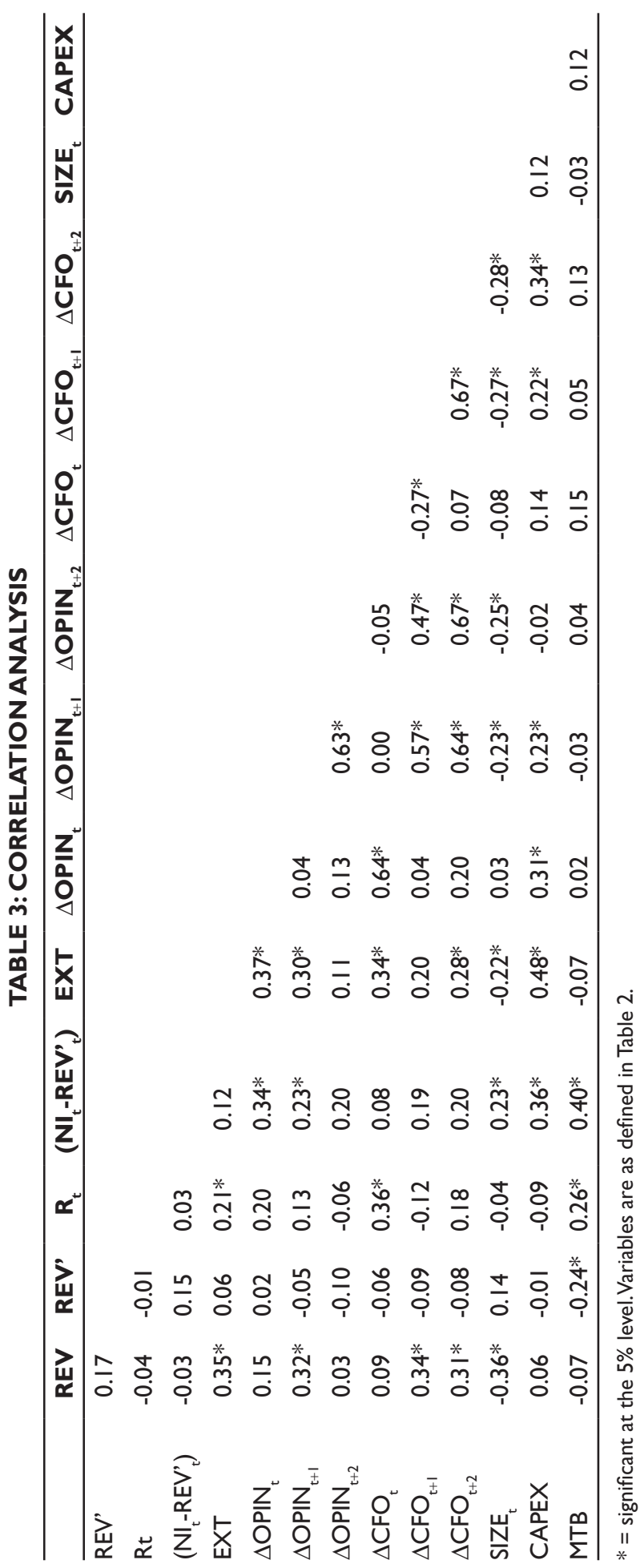


to the change in cash flows from operations in the current year and MTB. It is a little surprising that it is not related to future operating performance. The firms in the extractive industries are of smaller size, have greater current and future profitability and have larger current stock returns than the other firms in the sample. They also display evidence of incurring higher current capital expenditure. As expected, the future operating performance measures are highly correlated with each other. Capital expenditure is positively related to future operating performance. This is to be expected and supports our decision to control for CAPEX in assessing the relationship between impairment reversals and future operating performance.

We next estimate Equation 1 to assess H1. The results of this estimation are outlined in Table 4. Neither pre-reversal net income nor the reversal is significantly related to returns. All of the explanatory power of the regression comes from the year dummies, which are not tabulated. It is well known that the explanatory power of earnings for returns comes from their ability to enhance predictions of future earnings. Collins, Pincus and Xie (1999) point out that negative earnings are not particular useful for this purpose so explain much less of returns than profits.

TABLE 4

Mode I: Return $_{t}=\gamma_{0}+\gamma_{1}$ REV $_{t}+\gamma_{2}\left(\mathrm{NI}_{t}-\mathrm{REV}_{t}\right)+u_{t}$

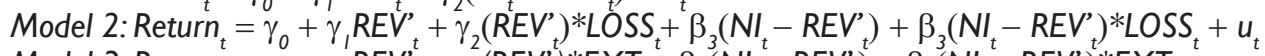
Model 3: Return $\left.{ }_{t}=\gamma_{0}+\gamma_{1} R E V_{t}^{t}+\gamma_{2}\left(R^{\prime} V_{t}^{\prime}\right) * E X T+\beta_{3}\left(N I_{t}^{t}-R E V_{t}^{\prime}\right)+\beta_{3}\left(N I_{t}^{t}-R E V_{t}^{\prime}\right)^{\prime}\right) * E T+u_{t}$

\begin{tabular}{|c|c|c|c|}
\hline & Model I & Model 2 & Model 3 \\
\hline Constant & $\begin{array}{l}-0.06 \\
(0.12)\end{array}$ & $\begin{array}{l}-0.4 \\
(0.22)\end{array}$ & $\begin{array}{l}-0.07 \\
(0.10)\end{array}$ \\
\hline $\mathrm{REV}_{\mathrm{t}}$ & $\begin{array}{l}-0.05 \\
(0.13)\end{array}$ & $\begin{array}{l}0.17 \\
(0.00)\end{array}$ & $\begin{array}{l}-0.41 \\
(0.14)\end{array}$ \\
\hline$\left(N I_{t}-R E V_{t}^{\prime}\right)$ & $\begin{array}{c}0.00 \\
(0.82)\end{array}$ & $\begin{array}{l}-0.007 \\
(0.02)\end{array}$ & $\begin{array}{l}0.21 \\
(0.12)\end{array}$ \\
\hline $\operatorname{REV}_{t}^{*}{ }^{*}$ LOSS $_{t}$ & & $\begin{array}{l}-0.21 \\
(0.01)\end{array}$ & \\
\hline$\left(N_{t}-R^{\prime} V_{t}^{\prime}\right)^{*}$ LOSS $_{t}$ & & $\begin{array}{l}0.03 \\
(0.32)\end{array}$ & \\
\hline REV $_{\mathrm{t}}^{*} \mathrm{EXT}$ & & & $\begin{array}{l}0.23 \\
(0.92)\end{array}$ \\
\hline$\left(N_{t}-R E V_{t}^{\prime}\right) * E X T$ & & & $\begin{array}{l}-0.25 \\
(0.03)\end{array}$ \\
\hline $\mathrm{R}^{2}$ & $17.9 \%$ & $19.9 \%$ & $20.3 \%$ \\
\hline
\end{tabular}

Time-varying intercepts are not reported.

$P$-values based on robust standard errors are in parentheses.

$R_{t}=$ stock market returns beginning 8 months before the financial year-end and ending 4 months after the financial year-end.

$\mathrm{REV}^{\prime}=$ the reversal amount scaled by market value 8 months before the fiscal year-end.

$\mathrm{NI}_{\mathrm{t}}-\mathrm{REV}_{\mathrm{t}}=$ net income before reversal in year $t$ scaled by market value of equity 8 months before fiscal year-end $t$. LOSS $_{t}$ is a dummy variable that takes the value of $\mathrm{I}$ if pre-reversal net income (NI-REV) is negative and zero otherwise.

EXT is a dummy variable which takes the value of I if the firm has an ICB sector code of 0530 (Oil \& Gas), I750 (Industrial Metals and Mining) or 1770 (Mining) and zero otherwise. 
Accordingly, we bifurcate our sample into firms whose pre-reversal net income is positive and those whose $N I_{t}-R E V^{\prime}{ }_{t}$ is negative. The column labelled model 2 in Table 4 reports results from estimating this model. We note that $R E V^{\prime}{ }_{t}$ is now positively related to returns but only for those companies whose pre-reversal net income is positive. In particular, the average $\mathrm{REV}^{\prime}{ }_{t}$ is 0.09 when $N I_{t}-R E V^{\prime}{ }_{t}$ is positive so an average-sized reveral is associated with a stock return increase of 0.09 $\mathrm{X} 0.17=1.5 \%$. When $N I_{t}-R E V_{t}^{\prime}$ is negative, the relationship between reversals and returns is significantly different from that when pre-reversal net income is positive: here a reversal is associated with an average stock decline of about 1.2 per cent. ${ }^{1}$ It appears that the market values reversals of impairments only when pre-reversal net incomes are positive. This may be explained by the valuation reason as outlined in Collins et al. (1999), or perhaps the market suspects that the reversal is undertaken for opportunistic reasons when pre-reversal net income is negative.

We noted earlier that the sample contains a disproportionate number of firms in the extractive industries. An alternative explanation for the poor performance of our simple returns-earnings model may be that the earnings of firms in these industries are not perceived as informative for share prices and returns as those in other industries. Thus we use a dummy variable, EXT, to separate our sample into firms in the extractive industries and others. The results of the regression pertaining to this dichotomisation of the sample are in the final column of Table 4: again, year dummies are not tabulated. These results show that the relation between earning and returns for firms in the extractive industry is significantly different from the relation between earnings and return in other industries. However, there is no apparent difference in how the market perceives the reversals of impairments for the extractive industries vis-à-vis other sectors.

As discussed above, the second, and more direct, method of assessing the veracity of the reversal of an impairment is to examine the relationship between the reversal and changes in future operating performance. We use two measures of operating performance: the change in operating cash flows and the change in operating income. If the increase in the asset value associated with an impairment reversal is justified then it should be positively associated with a change in both measures of operating performance.

We estimate Equations 2 and 2c where the change in operating cash flows over the first and second financial years after the reversal is predicted to be determined by current operating cash flows, the reversal and any concurrent capital expenditure that the firm might make (all variables scaled by opening total assets). Table 5 outlines the results pertaining to changes in subsequent operating cash flows. Columns 2,3 and 4 show that $R E V_{t}$ is significantly positively related to the change in operating cash flows for one and two years subsequent to the reversal. The coefficients indicate that an average reversal scaled by beginning total assets is associated with an increase of about 9 per cent in $\triangle C F O$ over the subsequent year: $0.008^{*} 1.14=0.0912$. CAPEX is also positively related to changes in subsequent operating cash flows as predicted. Additional control variables are used in columns 3 and 5. The results for CAPEX are unaffected by their inclusion. However, $R E V_{t}$ becomes insignificant when $\triangle C F O_{t+2}$ is the dependent variable. None of the control variables is significantly related to changes in future operating cash flows at the 5 per cent level. 
TABLE 5

\begin{tabular}{|c|c|c|c|c|}
\hline Dependent Variable & $\Delta$ CFO $_{t+1}$ & $\Delta \mathrm{CFO}_{\mathrm{t}+1}$ & $\Delta \mathrm{CFO}_{\mathrm{t}+2}$ & $\Delta \mathrm{CFO}_{\mathrm{t}+2}$ \\
\hline Constant & $\begin{array}{l}-0.01 \\
(0.22)\end{array}$ & $\begin{array}{c}0.05 \\
(0.33)\end{array}$ & $\begin{array}{l}-0.02 \\
(0.15)\end{array}$ & $\begin{array}{c}0.15 \\
(0.14)\end{array}$ \\
\hline $\mathrm{REV}_{\mathrm{t}}$ & $\begin{array}{c}1.14 \\
(0.00)\end{array}$ & $\begin{array}{c}0.95 \\
(0.05)\end{array}$ & $\begin{array}{c}1.29 \\
(0.05)\end{array}$ & $\begin{array}{c}0.47 \\
(0.61)\end{array}$ \\
\hline$\Delta C F O_{t}$ & $\begin{array}{l}-0.32 \\
(0.01)\end{array}$ & $\begin{array}{l}-0.32 \\
(0.02)\end{array}$ & $\begin{array}{c}0.01 \\
(0.95)\end{array}$ & $\begin{array}{l}-0.02 \\
(0.95)\end{array}$ \\
\hline$\Delta W C_{t}$ & & $\begin{array}{l}-0.05 \\
(0.54)\end{array}$ & & $\begin{array}{l}-0.21 \\
(0.20)\end{array}$ \\
\hline$S I Z E_{t}$ & & $\begin{array}{l}-0.005 \\
(0.15)\end{array}$ & & $\begin{array}{l}-0.01 \\
(0.06)\end{array}$ \\
\hline$M T B_{t}$ & & $\begin{array}{l}-0.003 \\
(0.46)\end{array}$ & & $\begin{array}{c}0.002 \\
(0.78)\end{array}$ \\
\hline CAPEX $_{t}$ & $\begin{array}{c}0.31 \\
(0.03)\end{array}$ & $\begin{array}{c}0.33 \\
(0.03)\end{array}$ & $\begin{array}{c}0.80 \\
(0.00)\end{array}$ & $\begin{array}{c}1.08 \\
(0.01)\end{array}$ \\
\hline $\begin{array}{l}\text { F-STAT } \\
\text { (p-value) } \\
\text { For Test of REV=CAPEX }\end{array}$ & $\begin{array}{c}5.11 \\
(0.03)\end{array}$ & $\begin{array}{c}1.51 \\
(0.22)\end{array}$ & $\begin{array}{c}0.52 \\
(0.47)\end{array}$ & $\begin{array}{c}0.21 \\
(0.65)\end{array}$ \\
\hline $\mathrm{R}^{2}$ & $24.4 \%$ & $33.9 \%$ & $22.6 \%$ & $32.3 \%$ \\
\hline
\end{tabular}

P-values based on robust standard errors are in parentheses.

Equations are estimated with year dummies (not reported in table).

Variables are as defined in Table 2.

Table 6 outlines the results for equivalent equations where $\triangle O P I N_{t+1}^{*}$ and $\triangle O P I N_{t+2}^{*}$ are the dependent variables. The coefficient on $R E V_{t}$ is significantly positive in both the basic and extended model when $\triangle \mathrm{OPIN}_{t+1}^{*}$ is the dependent variable, but it is not significant when $\triangle \mathrm{OPIN}{ }_{t+2}^{*}$ is the dependent variable. CAPEX is significant when $\triangle \mathrm{OPIN}_{t+1}^{*}$ is the dependent variable, but only at the 7 per cent level.

We note also that the coefficient on $R E V$ is significantly larger than that on CAPEX when one year ahead operating performance, $\triangle C F O_{t+1}$ or $\triangle \mathrm{OPIN}{ }_{t+1}^{*}$, is the dependent variable (see the penultimate row of Tables 5 and 6 ). There is no significant difference between the coefficients on REV and CAPEX in all other models. Thus the fair value measure of a change in asset value is at least as useful as the historical cost measure in all cases and more useful in two. Overall, the results outlined in Tables 5 and 6 support the prediction that an impairment reversal is positively related to future operating performance. It compares favourably with the more verifiable increase in asset value, CAPEX, as a predictor of changes in operating performance. This finding suggests that such reversals are, on average, reflective of genuine increases in asset values and are not opportunistic.

The results for the direct test do not appear to be entirely consistent with those reported for stock market returns that suggested that the market perceives reversals to be value relevant only when pre-reversal net income is positive. Accordingly, we 
TABLE 6

\begin{tabular}{|c|c|c|c|c|}
\hline Dependent Variable & $\Delta$ OPIN $^{*}{ }_{t+1}$ & $\Delta$ OPIN $^{*}{ }_{t+1}$ & $\Delta \mathbf{O P I N}^{*}{ }_{\mathrm{t}+2}$ & $\Delta$ OPIN $^{*}{ }_{t+2}$ \\
\hline Constant & $\begin{array}{c}0.00 \\
(0.60)\end{array}$ & $\begin{array}{l}-0.01 \\
(0.85)\end{array}$ & $\begin{array}{c}0.02 \\
(0.26)\end{array}$ & $\begin{array}{c}0.08 \\
(0.51)\end{array}$ \\
\hline $\operatorname{REV}_{t}$ & $\begin{array}{c}1.00 \\
(0.00)\end{array}$ & $\begin{array}{c}1.03 \\
(0.01)\end{array}$ & $\begin{array}{c}0.03 \\
(0.95)\end{array}$ & $\begin{array}{l}-0.24 \\
(0.68)\end{array}$ \\
\hline$\triangle O P I N_{t}$ & $\begin{array}{l}-0.06 \\
(0.67)\end{array}$ & $\begin{array}{l}-0.12 \\
(0.36)\end{array}$ & $\begin{array}{c}0.22 \\
(0.42)\end{array}$ & $\begin{array}{c}0.19 \\
(0.42)\end{array}$ \\
\hline$S I Z E_{t}$ & & $\begin{array}{c}0.00 \\
(0.92)\end{array}$ & & $\begin{array}{l}-0.00 \\
(0.54)\end{array}$ \\
\hline$M T B_{t}$ & & $\begin{array}{l}-0.01 \\
(0.19)\end{array}$ & & $\begin{array}{c}0.002 \\
(0.72)\end{array}$ \\
\hline CAPEX $_{t}$ & $\begin{array}{c}0.22 \\
(0.12)\end{array}$ & $\begin{array}{c}0.30 \\
(0.07)\end{array}$ & $\begin{array}{c}0.06 \\
(0.84)\end{array}$ & $\begin{array}{c}0.17 \\
(0.51)\end{array}$ \\
\hline $\begin{array}{l}\text { F-STAT } \\
\text { (p-value) } \\
\text { for Test of REV=CAPEX }\end{array}$ & $\begin{array}{c}5.74 \\
(0.02)\end{array}$ & $\begin{array}{c}1.94 \\
(0.17)\end{array}$ & $\begin{array}{c}0.01 \\
(0.92)\end{array}$ & $\begin{array}{c}0.41 \\
(0.53)\end{array}$ \\
\hline$R^{2}$ & $17.2 \%$ & $24.2 \%$ & $2.2 \%$ & $12.7 \%$ \\
\hline
\end{tabular}

P-values based on robust standard errors are in parentheses.

Equations are estimated with year dummies (not reported in table).

Variables are as defined in Table 2.

investigate the relations between reversal and future operating performance, controlling for situations when pre-reversal net income is negative. In particular, we estimate equations of the following form.

$\Delta C F O_{t+\tau}=\alpha+\beta_{1} \Delta C F O_{t}+\beta_{2} R E V_{t}+\beta_{3} R E V_{t}^{*}$ LOSS $_{t}+\beta_{4} C A P E X+\varepsilon_{t}$

LOSS $_{t}$ is a dummy variable that takes the value 1 if pre-reversal net income is negative in year $t$, and zero otherwise.

This equation is estimated for $\tau=1$ and 2 and equivalent models are estimated with $\Delta$ PPIN $_{t+\tau}^{*}$ as the dependent variable.

The results from estimating these models are outlined in Table 7 . Reversals for firms with pre-reversal profits predict future $\triangle C F O_{t+1}$ and $\Delta C F O_{t+2}: \beta_{2}$ is significantly positive in columns 2 and 3 of Table 7. The relationship between $\Delta C F O_{t+1}$ and reversals is significantly weaker for firms that have a pre-reversal loss because $\beta_{3}$ is significantly negative. However, the relationship between reversals and the change in operating cash flows remains significantly positive: $\beta_{2}+\beta_{3}$ is positive. There is no significant difference in the relationship between $R E V_{t}$ and $\triangle C F O_{t+2}$ for loss-making and profitable firms. However, the loss-making firms bring so much noise into the model that $\beta_{2}+\beta_{3}$ is not significantly different from zero; thus the reversals of firms with prereversal loss are not related to $\triangle C F O_{t+2}$. 
TABLE 7

\begin{tabular}{|c|c|c|c|c|}
\hline Dependent Variable & $\Delta$ CFO $_{t+1}$ & $\Delta \mathrm{CFO}_{\mathrm{t}+2}$ & $\Delta \mathbf{O P I N}_{\mathrm{t}+1}^{*}$ & $\Delta$ OPIN $^{*}{ }_{t+2}$ \\
\hline Constant & $\begin{array}{l}-0.01 \\
(0.19)\end{array}$ & $\begin{array}{l}-0.02 \\
(0.10)\end{array}$ & $\begin{array}{c}0.00 \\
(0.61)\end{array}$ & $\begin{array}{c}0.03 \\
(0.13)\end{array}$ \\
\hline$\Delta \mathrm{CFO}_{\mathrm{t}}$ & $\begin{array}{l}-0.32 \\
(0.01)\end{array}$ & $\begin{array}{l}-0.00 \\
(0.98)\end{array}$ & & \\
\hline$\Delta \mathrm{OPIN}_{\mathrm{t}}$ & & & $\begin{array}{l}-0.04 \\
(0.80)\end{array}$ & $\begin{array}{c}0.29 \\
(0.30)\end{array}$ \\
\hline $\operatorname{REV}_{t}$ & $\begin{array}{c}1.68 \\
(0.00)\end{array}$ & $\begin{array}{c}1.31 \\
(0.05)\end{array}$ & $\begin{array}{c}0.77 \\
(0.08)\end{array}$ & $\begin{array}{c}0.20 \\
(0.66)\end{array}$ \\
\hline REV $_{t}$ LOSS $_{t}$ & $\begin{array}{l}-1.09 \\
(0.01)\end{array}$ & $\begin{array}{c}4.34 \\
(0.45)\end{array}$ & $\begin{array}{c}0.45 \\
(0.30)\end{array}$ & $\begin{array}{l}-7.29 \\
(0.00)\end{array}$ \\
\hline CAPEX $_{t}$ & $\begin{array}{c}0.28 \\
(0.04)\end{array}$ & $\begin{array}{c}0.80 \\
(0.00)\end{array}$ & $\begin{array}{c}0.23 \\
(0.12)\end{array}$ & $\begin{array}{l}-0.01 \\
(0.98)\end{array}$ \\
\hline$\beta_{2}+\beta_{3}$ & $\begin{array}{c}0.59 \\
(0.00)\end{array}$ & $\begin{array}{c}5.65 \\
(0.33)\end{array}$ & $\begin{array}{c}1.22 \\
(0.00)\end{array}$ & $\begin{array}{l}-7.09 \\
(0.00)\end{array}$ \\
\hline $\mathrm{R}^{2}$ & $27.5 \%$ & $23.1 \%$ & $17.9 \%$ & $9.4 \%$ \\
\hline
\end{tabular}

P-values based on robust standard errors are in parentheses.

Equations are estimated with year dummies (not reported in table).

Variables are as defined in Table 2.

The results pertaining to $\triangle O P I N^{*}{ }_{t+\tau}$ are outlined in the final two columns of Table 7. The coefficient on $R E V$ is significantly positive when $\triangle O P I N^{*}{ }_{t+1}$ is the dependent variable: a reversal predicts an improvement in the subsequent year's operating performance when pre-reversal earnings are positive. We notice that there is no difference in the relationship between profitable and loss-making firms in the first year subsequent to the reversal: $\beta_{3}$ is insignificant. The significance of $\beta_{2}+\beta_{3}$ confirms that the change in operating income is predicted by the reversals of firms with pre-reversal losses. Reversals are not significantly related to $\triangle O P I N_{t+2}^{*}$ even for firms with positive pre-reversal net income: $\beta_{2}$ is insignificant. However, reversals for loss-making firms have a significantly different relation to those of profitable firms and their reversals have negative relation with $\triangle O P I N^{*}{ }_{t+2}$. Our results suggest that in the short term, the reversals of impairment charges for firms with negative pre-reversal earnings predict an improvement in performance but over a longer period they predict a disimprovement in operating performance. A possible explanation for this is that if a company is using reversals to manage earnings upward, it can maintain such earnings management in the short run but not in the longer term.

The results outlined in Table 7 suggest that in some scenarios the reversals of firms that have pre-reversal losses are reliable predictors of improvements in future operating performance whereas in others they are unreliable or even predict disimprovements of performance. The evidence outlined in Table 7 certainly provides some justification for some differences in the stock price reaction to the reversals of profit-makers and loss-makers. However, it is not clear that it fully justifies the 
complete discounting of the reversals of firms with pre-reversal losses as outlined in Table 4. It may be that when there is a prima facie case for earnings management using reversals, such as incurring a pre-reversal net loss, the market is unable to make any finer distinctions and will discount the reversals of all such firms. Therefore, this may be as much a problem of perception as it is of fact. The difference in the tenor between the results from the stock market tests and operating performance tests is contributed to by the indirect nature of the former. It may also be influenced by a lack of synchronicity in the timing of the reversal and the change in the stock market's perception of the firm's value. In particular, the market for the shares of some stocks may be efficient while that for stocks of other, particularly smaller AIM firms, may not. This may be important since the stock market tests require some degree of market efficiency to be useful.

\section{SUMMARY AND CONCLUSIONS}

This paper tests if changes in asset values and increases in net income effected by the reversal of impairment losses on PPE are justified by changes in subsequent operating performance and stock price performance. We find that stock price performance is only related to reversals in a manner that suggests a true increase in value has occurred when pre-reversal earnings are positive. A more direct test of whether an increase in the value of the impaired assets has actually occurred is to examine if the reversal is associated with future operating performance. In these tests we find clear evidence that the reversal of an impairment charge is significantly and positively related to changes in operating cash flows of the financial years subsequent to the reversal. Similar, albeit weaker, evidence is reported for changes in operating income. Additional tests reveal that the relationship between reversals and subsequent operating performance differs between firms with positive pre-reversal net income and those with negative pre-reversal net income in a manner that somewhat justifies the differential stock price reactions to the reversals between these two categories of firms. While reversals reported by profitable firms consistently predict an improvement in future operating performance, reversals reported by loss-making firms are entirely inconsistent. We find evidence that reversals are positively related, unrelated and even negatively related to future firm performance when firms have a pre-reversal loss. This suggests that some firms at least are using reversals to manage earnings upwards.

As anticipated, our direct tests provide clearer evidence that reversals, on average, reflect genuine changes in asset value. While our market and operating performance tests are broadly consistent, there are differences. We attribute some of the differences between our stock market and operating performance models primarily to the former being indirect and the latter being direct tests of the veracity of reversals. The indirect tests are affected by potential nonsynchronicity of the stock reaction to the reversal and the dependence of market performance on a broader set of variables. Further, when pre-reversal net income is negative, the market does not view reversals positively: the operating performance tests suggest that this is justified some but not all of the time. The market seems to be conscious that impairment 
reversals made by pre-reversal loss-making firms are likely to be more susceptible to manipulation and is conservative in reacting to them negatively in general. This 'cautious stance' by the market towards the reversals provides important, albeit limited, support for the adoption of fair value-based accounting standards. Although the market fails to differentiate between impairment reversals for genuine economic reasons and the ones driven by reporting incentives among loss-making firms, it nevertheless reacts to the reversals by profitable firms in a positive and 'correct' way, which is subsequently supported by future operating performance. Therefore, financial reporting from an investment perspective is improved by the adoption of IAS 36 in the UK, because at least investors and potential investors in profitable firms receive additional useful financial information regarding the firms of their concern. This should be considered a positive development in financial reporting.

Thus, broadly speaking, the empirical evidence provided by the current study lends support for the adoption of fair value accounting in valuing corporate assets. On average, it appears that firms in the UK reverse impairments in a manner that reflects genuine increases in the ability of their PPE assets to generate additional economic benefits. The market perceives reversals in the context in which they are made and does not value all reversals in the same way. We note that the generally positive relation between subsequent operating performance and reversals coupled with the discerning market reaction to them suggests that the decision of the IASB to allow impairment reversals is justified.

\section{ACKNOWLEDGEMENTS}

The authors would like to acknowledge the generous financial support received from Chartered Accountants Ireland Educational Trust which enabled this research to be undertaken. They would also like to acknowledge the helpful comments of two anonymous reviewers. All remaining errors are our own.

\section{ENDNOTES}

The average reversal when pre-reversal net income is negative is 29.7 per cent of market value. Accordingly, the influence of a reversal in this scenario is $0.297^{\star}(0.17-0.21)=-0.0119$ or about $-1.2 \%$.

\section{REFERENCES}

Aboody, D., Barth, M.E. and Kasznik, R. (1999). Revaluations of Fixed Assets and Future Firm Performance: Evidence from the UK, Journal of Accounting and Economics, Vol. 26, Nos 1-3, pp. 149-178.

Ball, R. (2006). International Financial Reporting Standards (IFRS): Pros and Cons for Investors, Accounting and Business Research, Vol. 26, Supplement 1, pp. 5-27.

Barth, M.E. (1994). Fair Value Accounting: Evidence from Investment Securities and the Market Valuation of Banks, The Accounting Review, Vol. 69, No. 1, pp. 1-25. 
Barth, M.E. and Clinch, G. (1998). Revalued Financial, Tangible, and Intangible Assets: Associations with Share Prices and Non-Market-Based Value Estimates, Journal of Accounting Research, Vol. 36, September, pp. 199-233.

Bens, D.A., Heltzer, W. and Segal, B. (2011). The Information Content of Goodwill Impairments and SFAS 142, Journal of Accounting, Auditing \& Finance, Vol. 26, No. 3, pp. 527-555.

Bernard, V.L. (1993). Discussion of an Investigation of Revaluations of Tangible Long-Lived Assets, Journal of Accounting Research, Vol. 31, Supplement, pp. 39-45.

Chen, S., Wang, Y. and Zhao, Z. (2009). Regulatory Incentives for Earnings Management through Assets Impairment Reversals in China, Journal of Accounting, Auditing \& Finance, Vol. 24, No. 4, pp. 589-620.

Collins, D.W., Pincus, M. and Xie, H. (1999). Equity Valuation and Negative Earnings: The Role of Book Value of Equity, The Accounting Review, Vol. 74, No. 1, pp. 29-61.

Duh, R.R., Lee, W.C. and Lin, C.C. (2009). Reversing an Impairment Loss and Earnings Management: The Role of Corporate Governance, The International Journal of Accounting, Vol. 44, No. 2, pp. 113-137.

Easton, P.D., Eddey, P.H. and Harris, T.S. (1993). An Investigation of Revaluation of Tangible Long-Lived Assets, Journal of Accounting Research, Vol. 31, Supplement, pp. 1-38.

Healy, P.M. and Wahlen, J. (1999). A Review of the Earnings Management Literature and Its Implications for Standard Setting, Accounting Horizons, Vol. 13, No. 4, pp. 365-383.

Henry, J. (2009). Do Firms Manage Fair Value Estimates? An Examination of SFAS 142 Goodwill Impairments, Journal of Business Finance and Accounting, Vol. 36, Nos. 9 \& 10, pp. 1059-1086.

Herrmann, D., Saudagaran, S.M. and Thomas, W.B. (2006). The Quality of Fair Value Measures for Property, Plant and Equipment, Accounting Forum, Vol. 30, No. 1, pp. 43-59.

Jordan, C.E. and Clark, S.J. (2004). Big Bath Earnings Management: The Case of Goowill Impairment under SFAS No 142, Journal of Applied Business Research, Vol. 20, No. 2, pp. 63-69.

Landsman, W. (1986). An Empirical Investigation of Pension Fund Property Rights, Accounting Review, Vol. LXI, No. 4 (Oct.), pp. 662-691.

Lapointe-Antunes, P., Cormier, D. and Magnan, M. (2009). Value Relevance and Timeliness of Transitional Goodwill-Impairment Losses: Evidence from Canada, The International Journal of Accounting, Vol. 44, No. 1, pp. 56-78.

Li, Z., Shroff, P.K., Venkataraman, R. and Zhang, I.X. (2011). Causes and Consequences of Goodwill Impairment Losses, Review of Accounting Studies, Vol. 16, No. 4, pp. 745-778.

Moehrle, S.R. (2002). Do Firms Use Restructuring Charge Reversals to Meet Earnings Targets?, The Accounting Review, Vol. 77, No. 2, pp. 397-413.

Nelson, K.K. (1996). Fair Value Accounting for Commercial Banks: An Empirical Analysis of SFAS No. 107, The Accounting Review, Vol. 71, No. 2, pp. 161-182.

Riedl, E.J. (2004). An Examination of Long-Lived Asset Impairment, The Accounting Review, Vol. 79, No. 3, pp. 823-852.

Sevin, S. and Schroeder, R. (2005). Earnings Management: Evidence from SFAS No. 142 Reporting, Managerial Auditing Journal, Vol. 20, No. 1, pp. 47-54.

Shaari, H., Cao, T.Y. and Donnelly, R. (2012). The Reversal of Impairment Losses, Future Firm Performance and Reporting Incentives: Evidence from Malaysia, paper presented at the Irish Accounting and Finance Association Annual Conference, NUI Galway, May 2012.

Titard, P.L. and Pariser, D.B. (1996). Impaired Assets: Meeting Users' Information Needs, Journal of Accountancy, Vol. 182, No. 6, pp. 55-61.

Trottier, K. (2013). The Effect of Reversibility on a Manager's Decision to Record Asset Impairments, Accounting Perspectives, Vol. 12, No. 1, pp. 1-22.

Zhang, R., Lu, Z. and Ye, K. (2010). How Do Firms React to the Prohibition of Long-Lived Asset Impairment Reversals? Evidence from China, Journal of Accounting and Public Policy, Vol. 29, No. 5, pp. 424-438. 